\title{
1 Sequestration of antimony on calcite observed by \\ 2 time-resolved nanoscale imaging
}

3 François Renard ${ }^{1,2}$, Christine V. Putnis ${ }^{3,4}$, German Montes-Hernandez ${ }^{2}$, Helen E. King ${ }^{5}$, Gijs D.

4 Breedveld ${ }^{1,6}$, Gudny Okkenhaug ${ }^{6,7}$

$5 \quad{ }^{1}$ Department of Geosciences, Physics of Geological Processes, University of Oslo, Norway

$6 \quad{ }^{2}$ Univ. Grenoble Alpes, CNRS, ISTerre, 38000, Grenoble, France

$7 \quad{ }^{3}$ Institut für Mineralogie, University of Münster, Corrensstrasse 24, 48149 Münster, Germany

$8{ }^{4}$ The Institute for Geoscience Research (TIGeR), Department of Chemistry, Curtin University,

9 Perth, 6845, Australia

$10{ }^{5}$ Department of Earth Sciences, Utrecht University Budapestlaan 4, 3584 CD Utrecht, The

11 Netherlands

${ }^{6}$ Norwegian Geotechnical Institute, box 3930, Ullevål Stadion, 0806 Oslo, Norway.

$13 \quad{ }^{7}$ Norwegian University of Life Sciences, Faculty of Environmental Sciences and Natural

14 Resource Management, box 5003, 1432 Ås, Norway

15

16 KEYWORDS. Antimony, Calcite, Romeite, Atomic Force Microscopy 
17 ABSTRACT. Antimony, which has damaging effects on the human body and the ecosystem, can be released into soils, ground- and surface waters either from ore minerals that weather in near surface environments, or due to anthropogenic releases from waste rich in antimony, a component used in batteries, electronics, ammunitions, plastics and many other industrial applications. Here, we show that dissolved $\mathrm{Sb}$ can interact with calcite, a widespread carbonate mineral, through a coupled dissolution-precipitation mechanism. The process is imaged in-situ, at room temperature, at the nanometer scale by using an atomic force microscope equipped with a flow-through cell. Time-resolved imaging allowed following the coupled process of calcite dissolution, nucleation of precipitates at the calcite surface and growth of these precipitates. $\mathrm{Sb}(\mathrm{V})$ forms a precipitate, whereas $\mathrm{Sb}(\mathrm{III})$ needs to be oxidized to $\mathrm{Sb}(\mathrm{V})$ before being incorporated in the new phase. Scanning-electron microscopy and Raman spectroscopy allowed identification of the precipitates as two different calcium-antimony phases $\left(\mathrm{Ca}_{2} \mathrm{Sb}_{2} \mathrm{O}_{7}\right)$. This coupled dissolution-precipitation process that occurs in a boundary layer at the calcite surface can sequester $\mathrm{Sb}$ as a solid phase on calcite, which has environmental implications as it may reduce the mobility of this hazardous compound in soils and groundwaters.

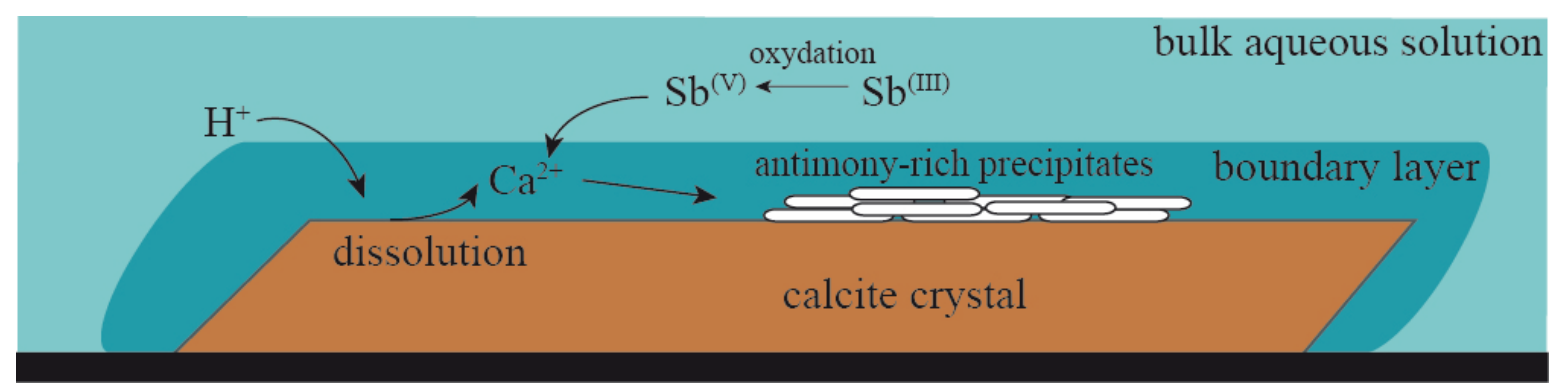


The environmental presence and behavior of antimony $(\mathrm{Sb})$, a hazardous substance as a solid or in solution, is gathering increased attention due to its increasingly extensive use in various products and its fate in the environment. The use of Sb includes applications as flame retardant in plastics, rubbers, textiles, brake pads, pigments, paints, ceramics, and semiconductor materials such as $\mathrm{GaSb}$ and $\mathrm{InSb}$ in electronic devices. In addition, it is present as a lead alloy in storage batteries and ammunitions. Substantial $\mathrm{Sb}$ emissions are related to mining and smelting activities and spent ammunitions at shooting ranges ${ }^{1,2}$. Its widespread use results in high concentrations present in waste, including air pollution control residues (i.e., ashes of flue gas treatment) from waste incineration ${ }^{3}$. Consequently, soils can show significant concentrations of $\mathrm{Sb}^{4,5}$, leading to elevated levels in soil pore water and groundwater ${ }^{5}$.

Antimony can be found in four oxidation states (-III, 0, III, and V), of which Sb(III) as neutral antimonite $\left(\mathrm{Sb}(\mathrm{OH})_{3}\right)$ and $\mathrm{Sb}(\mathrm{V})$ as antimonate $\left(\mathrm{Sb}(\mathrm{OH})_{6}^{-}\right)$oxyanion are the most common species in natural environments ${ }^{6}$. In oceans, the concentration of dissolved antimony is around $0.2 \mu \mathrm{g} \mathrm{L}{ }^{-1}$. In non-polluted freshwater ${ }^{7}$ it is usually below $0.2 \mu \mathrm{g} \mathrm{L}^{-1}$ but can sometimes reach 5 $\mu \mathrm{g} \mathrm{L}{ }^{-1}$, while the average concentration in world rivers ${ }^{6,8}$ is close to $1 \mu \mathrm{g} \mathrm{L}^{-1}$. Comparatively high concentrations of up to $95 \mu \mathrm{g} \mathrm{L}^{-1}$ antimony have been recorded in polluted groundwater and soils, where the antimony source was either natural, such as volcanic glass ${ }^{9}$, or anthropogenic e.g., contaminated soil and other industrial wastes ${ }^{6}$. Groundwater flowing out of an abandoned antimony mine near Goesdorf, Luxemburg ${ }^{8}$ was found to contain $\mathrm{Sb}$ at a concentration of up to

$53 \quad 2.2 \mathrm{mg} \mathrm{L}^{-1}$ at $\mathrm{pH} 7-8$. The concentration in alkaline groundwater $(\mathrm{pH} \sim 8)$ near an active mine in 
in the form of $\mathrm{Sb}(\mathrm{V})$. Laboratory leaching of similar mining impacted soils ${ }^{1}$ showed water extractable concentrations of up to $748 \mathrm{mg} \mathrm{kg}^{-1}$ of soils and concentrations in water of up to 103 mg $\mathrm{L}^{-1}$ after 7 days contact time, for a $\mathrm{pH}$ range between 5 and 7.

In calcium (Ca) rich environments as calcareous soils and alkaline waste materials, $\mathrm{Ca}$ is suggested as an important sink for $\mathrm{Sb}$. Calcium antimonates $\left(\mathrm{Ca}\left[\mathrm{Sb}(\mathrm{OH})_{6}\right]_{2}\right.$ and $\mathrm{Ca}_{1}{ }_{+} \mathrm{Sb}_{2} \mathrm{O}_{6} \mathrm{OH}_{2}-$ 2x) belong to the family of roméite minerals ${ }^{11}$. The solubility of roméite at room temperature ${ }^{12}$ and $\mathrm{pH} 8$ is of the order of $4 \mathrm{mg} \mathrm{L}^{-1}$. The solubility product of romeite varies as this mineral may contain vacancies and crystallographic defects that affect dissolution ${ }^{13}$. Solubility between $10^{-3.4}$ and $10^{-4.8} \mathrm{~mol} \mathrm{~L}^{-1}$ at $25^{\circ} \mathrm{C}$ has been proposed, with a factor 60 difference between extreme values $^{13}$. In several industrial waste systems, the solubility product of a hydrated calcium antimonate indicates this mineral should precipitate ${ }^{14}$. Based on XANES spectroscopy and equilibrium calculations, it has been proposed that this mineral controls the solubility of antimony in soils near active antimony mines in China ${ }^{1}$ or during the leaching of bottom ash from incinerated municipal waste ${ }^{14}$. However, to our knowledge, no direct evidence of the presence of roméite or another calcium antimony phase was provided in these studies, such as Raman spectroscopy or X-ray diffraction identification.

The dissolution-precipitation reaction of roméite at calcite interfaces could contribute to longterm spatial and temporal storage of antimony in carbonate-rich environments. The main objectives of the present study are to 1) characterize the coupling between calcite dissolution and precipitation of $\mathrm{Ca}-\mathrm{Sb}$ phase(s); 2) quantify the spatial and temporal evolution of the precipitate nuclei; 3) hypothesize if a coupled dissolution-precipitation process could immobilize $\mathrm{Sb}$ at the calcite surface. 
A calcite crystal (Iceland spar, Vizcaya, Mexico) was obtained from the Natural History Museum in London. ICP-OES (inductively coupled plasma - optical emission spectroscopy) analyses indicate the high purity of the calcite crystal, with trace amounts of $\mathrm{Mn}(31 \mathrm{ppb}), \mathrm{Mg}$ $(2.8 \mathrm{ppb})$ and $\mathrm{Sr}(11.4 \mathrm{ppb})$. Fresh calcite fragments (ca. 3 × 2 × $1 \mathrm{~mm})$ were prepared directly before each experiment by cleaving the calcite crystal parallel to the $\{10-14\}$ plane.

The calcite surfaces were scanned in a room with controlled temperature $\left(22 \pm 1^{\circ} \mathrm{C}\right)$ and humidity (40\%) using a Bruker Multimode Atomic Force Microscope (AFM) operating in contact mode (Supporting Information). At the beginning of each experiment, deionized water was injected over the calcite surface for several minutes, to observe any reaction or dissolution. Then, antimony-free solutions and solutions with a controlled amount of $\mathrm{Sb}(\mathrm{Sb}(\mathrm{III})$ or $\mathrm{Sb}(\mathrm{V}))$, with the same constant ionic strength $(0.05 \mathrm{M})$ and various controlled $\mathrm{pH}$ values between 2 and 8, were injected (Table S1). Several solutions with identical compositions were used to test the reproducibility of the obtained results.

The same procedure described below was followed in each experiment to ensure results could be compared between experiments. Firstly, deionized water was injected for 10 minutes and 5 images were acquired. Secondly, a solution without $\mathrm{Sb}$ and at the desired constant $\mathrm{pH}$ was injected for another 10 minutes and 5 images were acquired. Thirdly, solutions with increasing Sb concentrations were injected, with 5 images acquired at 1.5 minute intervals, then the AFM tip was lifted for 10 minutes after which another image was acquired, then the AFM tip was lifted for 1 hour and a further series of AFM images were acquired. Following this procedure, calcite dissolution was followed in the AFM for several hours. As a consequence, the injection 
was intermittent, with an average flow rate of $22 \mu \mathrm{L} \cdot \mathrm{s}^{-1}$ and residence time between 1.5 minute and several hours (Supplementary Information). Then the sample was removed from the flowthrough cell, left in contact with the solution for 12 to 20 hours to allow sufficient time for reaction, and then imaged again. The same samples were used for scanning electron microscopy imaging and Raman spectroscopy characterization (Supporting Information).

\section{Results}

Dissolution at calcite surface: The cleaved calcite $\{10-14\}$ surface is characterized by the presence of steps (Figure S1a). Direct in situ observations showed that in contact with water and aqueous solutions the calcite surface dissolves along steps that retreat, as well as through the formation of etch pits with typical rhombohedral shapes (Figure S1b). Etch pit steps were typically one unit cell (3.1 $\AA$ ) high, before deepening. These pits spread sideways to merge and remove successive unit-cell heights layer by layer. The average spreading rate $v_{a v g}=\left(v_{+}+v_{-}\right) / 2$ was measured from etch pits spreading between two successive AFM scans. Here, v+ and v- are the velocities of the obtuse and acute steps of etch pits, respectively ${ }^{15}$. At $\mathrm{pH}$ below 4 , the dissolution was so fast that it was not possible to measure etch pit spreading rates. At $\mathrm{pH}$ between 4.5 and 8 , spreading rates and their standard deviation could be calculated from multiple measurements and found to fall in the range $v_{\text {avg }}=2.6 \pm 1.3$ to $4.1 \pm 0.5 \mathrm{~nm} \cdot \mathrm{s}^{-1}$, a range of values previously reported for calcite ${ }^{15}$. No clear effect of $\mathrm{Sb}$ on the overall etch pit spreading rate could be observed. However, in all experiments where $\mathrm{Sb}(\mathrm{V})$ was injected, the shape of the initial rhombohedral etch pits evolved within minutes to show a rounding curve at the obtuse corner that seemed to be pinned (Figure S1c, d). 
121 height of a few nanometers, just within the limits of AFM recognition under the given fluid conditions and contact mode. They were distributed at kink sites on the calcite surface (Figure 1) and showed low adhesion, as they were easily moved by the scanning AFM tip at the initial stage of precipitation. With time, they tended to localize near step edges (Figure 1) or near deep etch pits (Figure 2b) or, close to locations where dissolution was more intense. This means that dissolution sites where more calcium was released control the nucleation process of the precipitates. Initially the precipitates nucleated as individual particles with a rounded shape (Figure S2a). Then these particles either piled up or aggregated to form larger particle clusters

129 (Figure S2 b-d). They grew in size into larger rounded structured aggregates until they covered 130 the whole calcite surface (Figure 2a). Even at this stage, they were weakly attached to the 131 surface, as successive scans on the same area showed that fewer particles were present than in 132 the surroundings (Figure 2a), which we interpret by the displacement of particles by the scanning 133 AFM tip.

134 The shape and size of these precipitates could be measured in all experiments where they were 135 observed and all showed that they formed patches with a more or less circular perimeter, a low height to diameter aspect ratio (Figure S3), and no evidence of crystallographic facets at the onset of precipitation. We have chosen to measure particles whose diameter is larger than 100 nanometers, the spatial resolution of the AFM technique used here. With time, some of these

139 particles developed facets (Figure S2d). Images were collected at different times, under different 140 conditions, and over differing areas of observation. Under all these conditions the precipitated 141 particles presented rounded perimeters. At the scale of the AFM observations tip-shaped 142 convolutions would therefore be minimal. The height and diameter of the precipitates measured 
for all experiments (Figure 3) show that initially particles were quite flat $(\sim 10 \mathrm{~nm})$, with a

144 diameter in the range 100-200 nm. These particles formed within 2 minutes after the injection of

$145 \mathrm{Sb}$. With time, particles tended to grow in height, while keeping a maximum diameter smaller

146 than $800 \mathrm{~nm}$ and within the range $300-800 \mathrm{~nm}$. During this stage, particles aggregated or merged

147 together and then grew in height to $20-120 \mathrm{~nm}$. For three experiments the same particles could be 148 followed in a time sequence and their height to diameter ratio showed a positive trend with time

149 (Figure S3), demonstrating that particles first grew laterally (by the merging of smaller particles), 150 as thin discs and then grew more continuously in height. In one experiment, a linear fit of the 151 particle height with time could be performed and gives a growth rate of $0.016 \mathrm{~nm} \cdot \mathrm{s}^{-1}$ (Figure $152 \mathrm{~S} 4 \mathrm{~b}$ ), whereas the diameter of the precipitates did not change significantly (Figure S4a). .With 153 time the calcite surface became covered by these particles that produced several layers of 154 precipitates (Figure 2a). These observations were seen for acidic fluids in the presence of Sb; the 155 lower the $\mathrm{pH}$, the faster the calcite dissolved and more particles precipitated. Many more 156 particles nucleated and grew in the presence of $\mathrm{Sb}(\mathrm{V})$ as compared to $\mathrm{Sb}(\mathrm{III})$.

157 Identification of the precipitates: Evidence for dissolution of the calcite surface and 158 precipitation of a new phase was also observed in the SEM (Figure 4a) on calcite samples left 24 159 hours in the $\mathrm{Sb}$ solutions. In the $200 \mathrm{ppm} \mathrm{Sb}(\mathrm{V})$ solutions at $\mathrm{pH} 5$ the calcite surface was covered 160 in precipitates along with rhombohedral etch pits seen in Figure $4 \mathrm{~b}$. The precipitates were 161 between 5 and $25 \mu \mathrm{m}$ width. These particles had clear crystal facets indicating a crystalline 162 structure and showed a consistent dipyramidal form (Figure $4 \mathrm{~b}$ ). Incorporation of Sb into the 163 particles was confirmed by comparison of the EDX spectra for the particles, which showed peaks 164 for $\mathrm{Ca} \mathrm{K} \alpha, \mathrm{K} \beta$ and $\mathrm{Sb} \mathrm{L} \alpha \mathrm{L} \beta$ in the spectral region between 3 to $5 \mathrm{keV}$, and the underlying 165 calcite surface (Figure 4c). Raman spectroscopy of the precipitates produced spectra (Figure 4d) 
with peaks listed in Table S2. The small, sharp band at $1086 \mathrm{~cm}^{-1}$ is consistent with the symmetrical stretch of carbonate in the underlying calcite crystal $^{16}$, as are the smaller peaks at 156, 283 and $711 \mathrm{~cm}^{-1}$. The rest of the peaks therefore originate from the precipitate itself. The dominant peak in the spectrum at $624 \mathrm{~cm}^{-1}$ and the smaller peak at $384 \mathrm{~cm}^{-1}$ correspond well with previously published synthetic $\mathrm{Ca}_{2} \mathrm{Sb}_{2} \mathrm{O}_{7}$ Raman spectra ${ }^{17}$. This mineral was also observed to form in hydrothermal experiments where calcite was left in contact with dissolved $\mathrm{Sb}^{18}$. However, the strong Raman peak documented for synthetic $\mathrm{Ca}_{2} \mathrm{Sb}_{2} \mathrm{O}_{7}$ at $472 \mathrm{~cm}^{-1}$ is not present in the spectra obtained from the precipitates. Similarly the published spectra do not show evidence for peaks around $500 \mathrm{~cm}^{-1}$ that are visible in Figure $4 \mathrm{~d}$. This could be related to crystal orientation, which is known to change the relative intensities of peaks within the Raman spectra $^{19}$. However, it may also be related to the precipitate chemistry or mixed phase as Raman spectra $^{20}$ from the natural mineral oxycalcioroméite $\left(\mathrm{Ca}_{2} \mathrm{Sb}_{2} \mathrm{O}_{6} \mathrm{O}\right)$ with a more varied composition and cubic structure show dominant peaks around $500 \mathrm{~cm}^{-1}$.

\section{Discussion}

Dissolution-precipitation in a boundary layer: The interactions of calcite with oxyanions, such as arsenic or selenium, were reported in previous studies ${ }^{21,22,23}$, where it was shown that etch pit corners could be pinned during dissolution to result in etch pit shapes deviating from normal rhombohedral etch pits, characteristic of calcite dissolving in water ${ }^{15}$. In the present study, a similar effect was observed, demonstrating that Sb interacts with kink sites in etch pits and slightly modify the dissolution process. However, this pinning does not have a measurable effect on the etch pit dissolution rate that remained within the average rate for calcite in pure water (2-4 $\left.\mathrm{nm} \cdot \mathrm{s}^{-1}\right)$. 

becomes increasingly saturated with $\mathrm{Ca}^{2+}$ and $\mathrm{CO}_{3}{ }^{2-}$ ions, this last species being protonated into $\mathrm{HCO}_{3}{ }^{-}$at neutral and low $\mathrm{pH}$. When the calcite surface is in contact with the Sb-bearing solution, the interfacial fluid becomes supersaturated with a new $\mathrm{Ca}-\mathrm{Sb}$ phase that can then precipitate. It is now well-established, using real-time phase-shift interferometry and ion-specific microelectrodes, that interfacial mineral-fluids can become supersaturated with a new phase when the bulk solution is undersaturated ${ }^{24}$. This interface-coupled dissolution-precipitation process ${ }^{25,26}$ is summarized in the graphical abstract and involves the dissolution of the calcite substrate, releasing $\mathrm{Ca}^{2+}$, followed simultaneously by the nucleation of precipitates, initially only less than 10 nanometers in diameter. The small rounded precipitate particles grew in diameter, until they

198 reached a size in the range $300-800 \mathrm{~nm}$, and then grew in height to $20-120$ nanometers.

199 Observations indicate that the initial particles merged with adjacent particles (Figures 3c; S2b, 200 S2d). With time the calcite surface became covered by these particles that produced several layers of precipitates (Figure 2a). There is therefore a balance between nucleation of new precipitates and growth of existing ones.

203 Mechanism of dissolution precipitation: The interface coupled dissolution-precipitation 204 reactions at the calcite surface can be schematically represented as follows:

$$
\equiv \mathrm{CaCO}_{3}+\mathrm{H}^{+} \rightarrow \mathrm{Ca}^{2+}+\mathrm{HCO}_{3}^{-}
$$

$$
C a^{2+}+S b^{(V)} \rightarrow C a-S b^{(V)} \text { phase }
$$

207 The appearance of tiny (few $\mathrm{nm}$ ) particles on the dissolving calcite surface and their subsequent merging with adjacent particles tends to indicate a heterogeneous growth process that may be initiated as pre-nucleation clusters within the calcite-fluid boundary layer. The growth of 
the precipitate does not follow a classical homogeneous mechanism ${ }^{27}$ that would require the

211 addition of growth building ionic species to step edges and kink sites. Instead, given the

212 limitations of our AFM observations, the first particles already with a diameter of a few

213 nanometers appeared within seconds and at most within 1.5 minutes during one scan on the

214 dissolving calcite surface. To do this, it could be assumed that some ionic species association had

215 already occurred within the fluid boundary layer. Gebauer et al. ${ }^{28}$ have shown that stable pre-

216 nucleation ion clusters of calcium carbonate form even in undersaturated solutions. In our case

217 the Sb-bearing solution is undersaturated with respect to any possible Ca-phase but precipitation

218 is clearly observed on a dissolving surface. The current understanding of the mechanism of phase

219 separation allowing for the initial formation of solid particles is an active topic of research ${ }^{28}$

220 because of the application to many geochemical systems including biomineralisation. However,

221 the formation of stable pre-nucleation clusters can be explained in terms of equilibrium

222 thermodynamics that would promote some form of structural orientation between ions in solution

223 resulting in an association of ionic species forming the initial denser cluster form. From our

224 AFM observations it is not clear whether the initial 1-2 nanometer particles nucleate directly on

225 the calcite surface or arrive at the surface already as "clusters" that have formed as pre-

226 nucleation clusters within the near-surface boundary fluid layer. The latter scenario seems highly

227 likely, given that the observations showed immediate precipitation of particles as soon as the

228 calcite surface was in contact with a Sb-bearing solution.

229 The precipitation of the new phase was observed to increase with a decrease in $\mathrm{pH}$, which is 230 consistent with a faster dissolution rate of calcite at lower $\mathrm{pH}$ and therefore a faster release of $231 \mathrm{Ca}^{2+}$ ions required for the precipitation of the new phase. Therefore we could reasonably expect 232 that a Ca-antimonate phase is likely to precipitate at the calcite surface. Initially, these 
precipitates have a disc shape and do not show facets. With time, they develop facets (Figures

$234 \mathrm{~S} 2 \mathrm{~d}$ and 4). $\mathrm{Ca}_{2} \mathrm{Sb}_{2} \mathrm{O}_{7}$ has an orthorhombic crystal structure similar to weberite $\left(\mathrm{Na}_{2} \mathrm{MgAlF}_{7}\right)^{29}$, and often forms with a dipyramidal habit unlike oxycalcioroméite, which is isometric. Therefore, the formation of dipyramids in combination with the dominant Raman band at $624 \mathrm{~cm}^{-1}$ indicates that the precipitated phase is dominantly orthorhombic $\mathrm{Ca}_{2} \mathrm{Sb}_{2} \mathrm{O}_{7}$. However, additional bands at $500 \mathrm{~cm}^{-1}$ in the Raman spectrum indicate some of the isometric phase is also present in the precipitates. The structure of the Ca-antimonate has been shown to be sensitive to the presence of ions such as $\mathrm{F}^{-}$, where increase in these ions within the crystal structure encourages the formation 241 of the isometric rather than the orthorhombic form ${ }^{30}$. Whether the mixed phase is due to a phase 242 transformation during or after the experiment is unclear from the ex-situ data. As Sb-rich fluid is 243 injected in the AFM flow-through cell, the release of Ca ions at the calcite surface, will be more 244 concentrated near active dissolution sites such as at the bottom of etch pits or kinks. Here precipitates are initially more numerous (Figures 1, 2b). At these locations, the concentration products of $\mathrm{Ca}_{2} \mathrm{Sb}_{2} \mathrm{O}_{7}$, and probably oxycalcioroméite, are large enough to reach supersaturation with respect to these minerals and result in their subsequent precipitation. The precipitates grow initially as disc-shaped particles; that agglomerate into larger particles, evolving towards fully crystallized $\mathrm{Ca}_{2} \mathrm{Sb}_{2} \mathrm{O}_{7}$ and oxycalcioroméite crystals. Such a coupled dissolution-precipitation process on carbonates has also been reported for the precipitation of a $\mathrm{Ca}$ arsenate phase on calcite $^{23}$ and the formation of a Ca-selenate phase on calcite ${ }^{22}$. These examples provide a mechanism of possible sequestration of environmentally harmful elements. More generally, such coupled replacement reactions are widespread in mineral-water systems ${ }^{31}$ whenever the release 254 of ions from the dissolving mineral is coupled to the precipitation of a new phase at the surface 255 of a dissolving mineral. 
Environmental implications: The present results show that coupled to calcite dissolution, $\mathrm{Ca}$ -

$257 \mathrm{Sb}$ phases precipitate as nanometer size particles on the calcite surface (heterogeneous nucleation). Primary nanoparticles are then self-assembled into rounded aggregates that coalesce to form larger particle aggregates averaging 130-220 $\mathrm{nm}$ wide and up to $80 \mathrm{~nm}$ high that cover

260 the carbonate surface. There are much fewer particles at high (8) than low (2.5) $\mathrm{pH}$ and fewer 261 particles in the presence of $\mathrm{Sb}(\mathrm{III})$ than in the presence of $\mathrm{Sb}(\mathrm{V})$. As confirmed by Raman 262 spectroscopy, these particles are predominately $\mathrm{Ca}_{2} \mathrm{Sb}_{2} \mathrm{O}_{7}$ (and probably minor 263 oxycalcioroméite). Furthermore, we could not find any evidence for the formation of the 264 hydrated romeite crystalline salt $\mathrm{Ca}\left[\mathrm{Sb}(\mathrm{OH})_{6}\right]_{2}$, that has been suggested to explain unexpectedly 265 low Sb concentrations in extracts of alkaline soils ${ }^{1,12,32}$. This phase may possibly form at higher $266 \mathrm{pH}$ values that could be consistent with ground water in alkaline soils. If this phase was present 267 in the experiments, it could not be detected in the Raman data.

268 As a consequence of the interaction of calcite surfaces with Sb-bearing solutions, antimonate 269 can be sequestered in a solid form on calcite surfaces by a coupled dissolution-precipitation 270 process in a boundary fluid layer. These results provide a mechanistic understanding of 271 environmental studies where a Ca-antimonate phase was proposed to form, but could not 272 previously be observed in-situ ${ }^{1,4,12}$. Therefore, it is reasonable to suggest that calcite or other soluble Ca-bearing surfaces could provide a realistic environmental remediation strategy in the case of elevated $\mathrm{Sb}$ concentrations related to acid mine drainage systems, contaminated shooting range soil and ashes from waste incineration. 

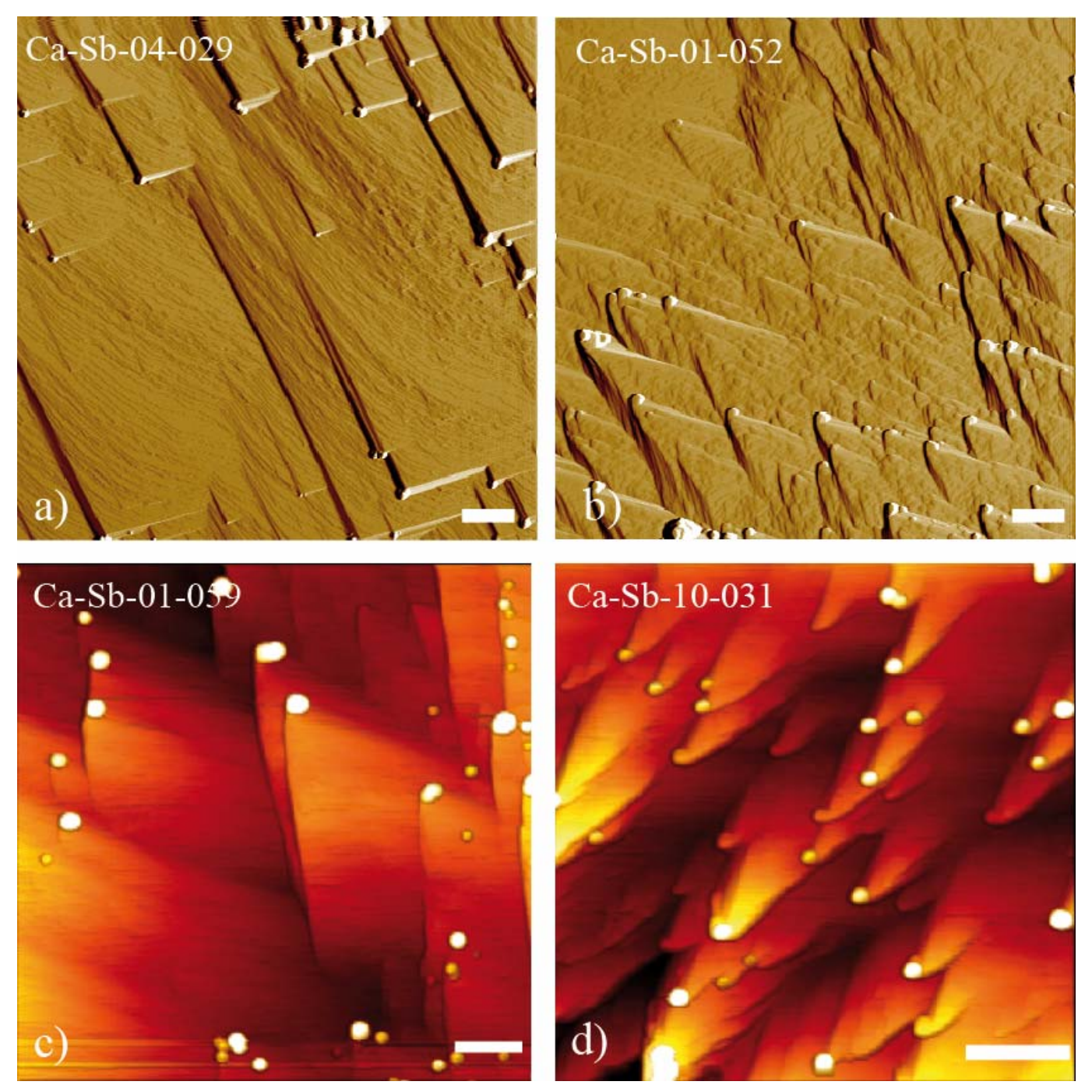

277 Figure 1. AFM images showing nucleation of precipitates (white spots) at step kinks on a calcite 278 surface. a-c) 2D images in deflection mode. c-d) 3D rendering in height mode. Solution

279 compositions are: a) 50 ppm Sb(V), pH 3.2. b-c) 200 ppm Sb(V), pH 3; d) 5 ppm Sb(III), pH 3

280 (here probably the $\mathrm{Sb}(\mathrm{III})$ oxidized into $\mathrm{Sb}(\mathrm{V})$ ). These data demonstrate that the antimony-rich

281 precipitates nucleate near step kinks where supersaturation with respect to the new phase is also

282 most likely. Deposits pin the steps at those points and thus inhibit dissolution locally as the steps

283 dissolve around them, hence the appearance of the finger-like morphology emanating from these 284 pinned points. Scale bar $1 \mu \mathrm{m}$. 

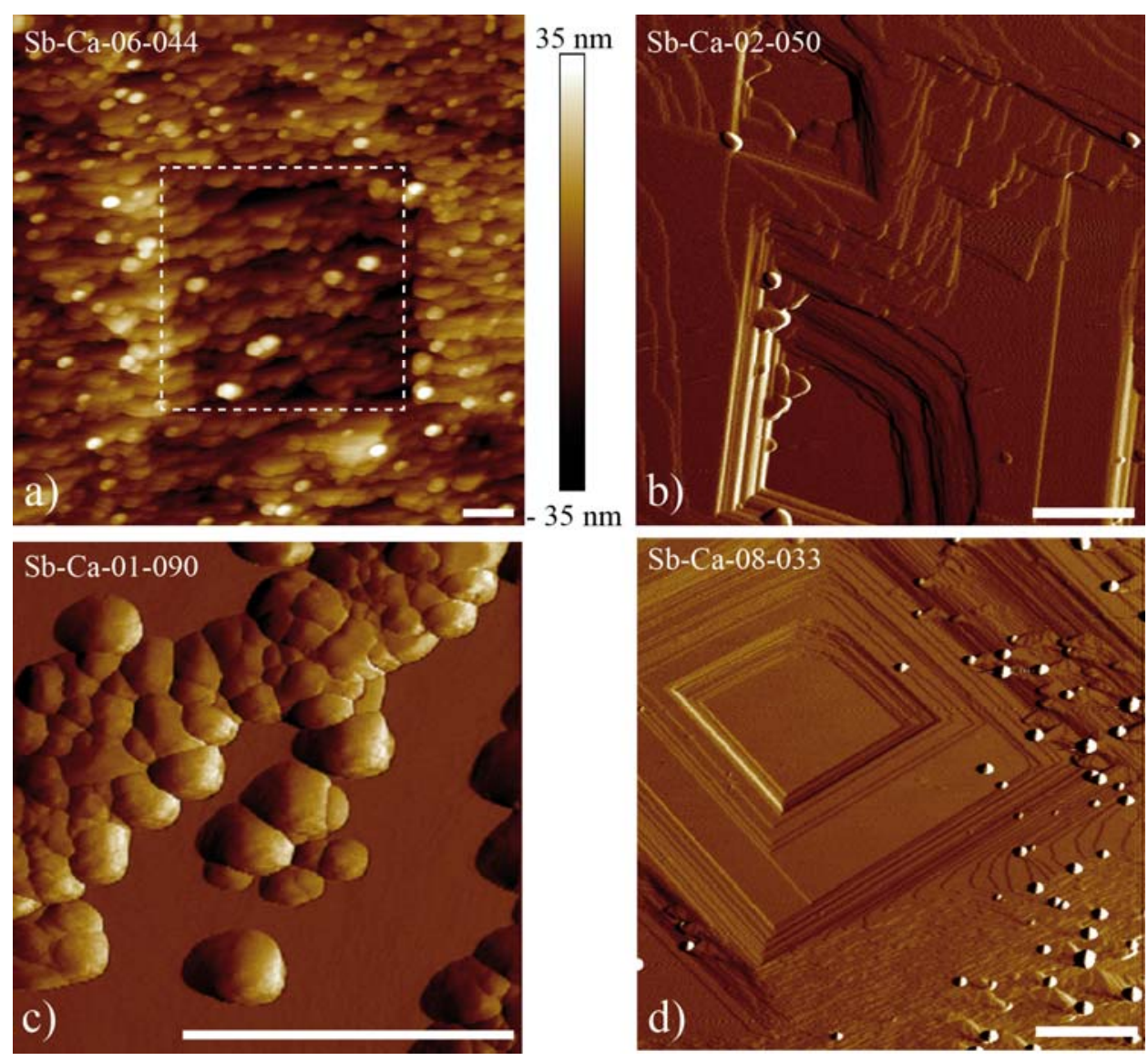

286 Figure 2. AFM images (deflection mode) of calcium-antimony precipitates on a calcite surface.

287 Scale bar: $1 \mu \mathrm{m}$ for all images. a) Calcite surface, 10x10 $\mu \mathrm{m}^{2}$, covered with calcium-antimonate

288 precipitates. The central area, outlined by a dashed square, corresponds to a $5 \times 5 \mu \mathrm{m}^{2}$ area

289 scanned previously and contains less precipitates. This demonstrates that precipitates are weakly

290 attached as some are removed by the AFM tip during scanning. Solution $\mathrm{Sb}(\mathrm{V}) 200 \mathrm{ppm}, \mathrm{pH}$ 2.5.

291 b) Etch pits on calcite surface with precipitates along actively dissolving edges. The location of

292 the precipitates is related to the location of higher dissolution. Solution $\mathrm{Sb}(\mathrm{V}) 200 \mathrm{ppm}, \mathrm{pH} 5.1$.

293 c) Image (deflection mode) of a calcite surface after 12 hours in solution $\mathrm{Sb}(\mathrm{V}) 200 \mathrm{ppm}, \mathrm{pH} 3$

294 showing precipitates of calcium-antimonate that form individual patches that then agglomerate.

295 d) Image (deflection mode) of a calcite surface in solution Sb(III) $10 \mathrm{ppm} \mathrm{pH} \mathrm{3,} \mathrm{with} \mathrm{very} \mathrm{few}$

296 precipitates of calcium-antimonate demonstrating that $\mathrm{Sb}(\mathrm{III})$ form much fewer precipitates. 


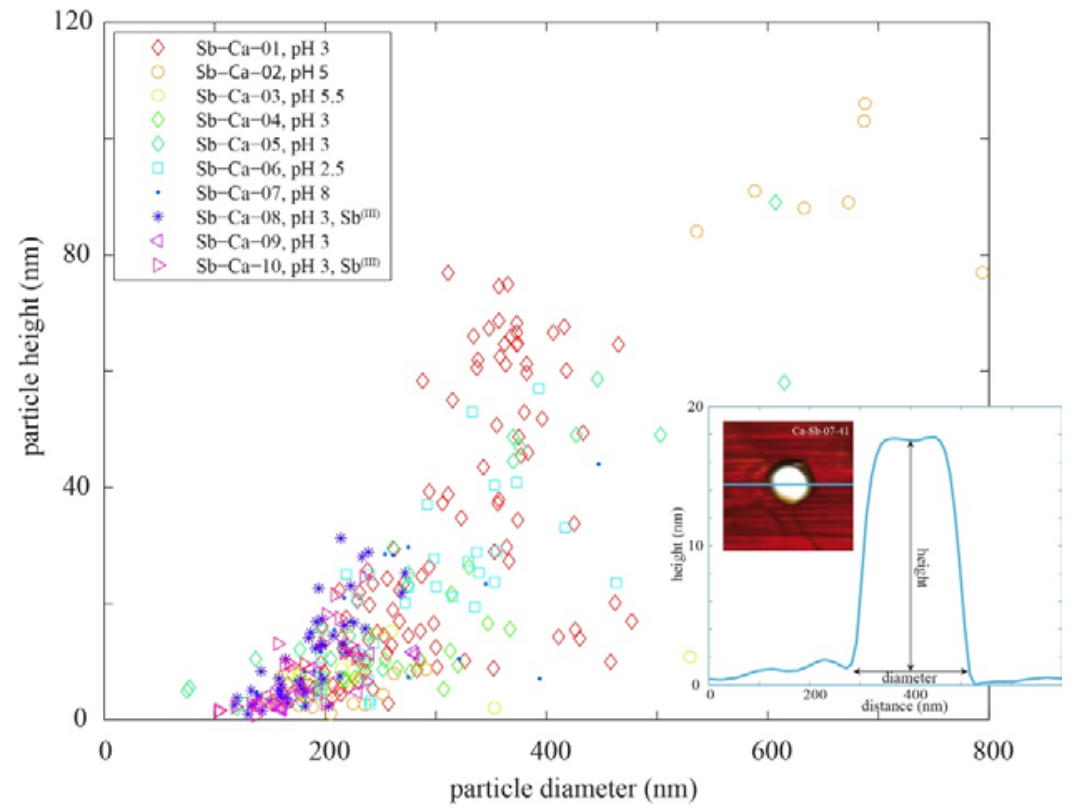

298 Figure 3. Height versus diameter of $\mathrm{Ca}$-Sb nanoparticles in all AFM experiments. Inset: Height

299 profile across a nanoparticle and definition of the height and diameter. 

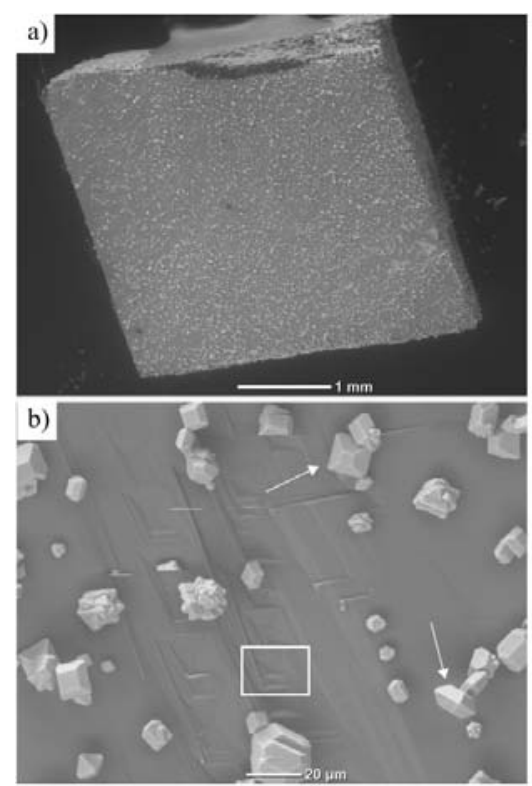

c)

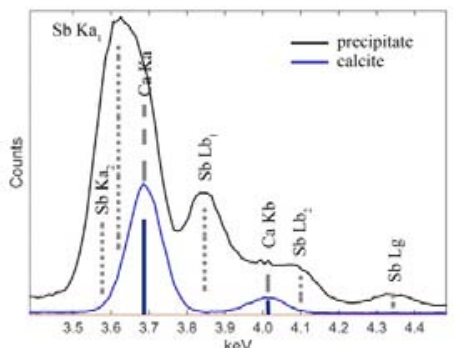

d)

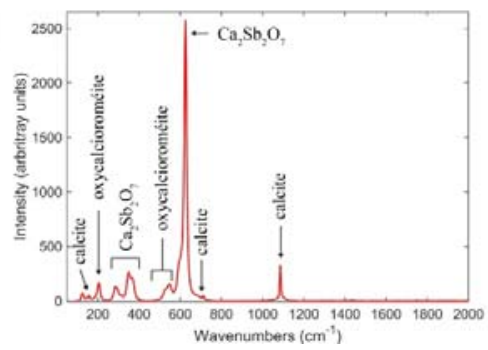

Figure 4. SEM images and EDX and Raman spectra of Ca-Sb precipitates. a) SEM image of the

302 calcite surface with precipitates at the surface (exp. Sb-Ca-5). b) Higher resolution image of the

303 precipitates showing their typical dipyramidal structures (white arrows) and the presence of etch

304 pits on the underlying calcite surface (white box). c) EDX spectra focused on the region between

3053.4 and $4.5 \mathrm{eV}$ showing the overlapping $\mathrm{Sb}$, Ca peaks (blue: underlying calcite surface, grey: precipitate). d) Typical Raman spectrum of the precipitate with phases labelled based on published spectra for oxycalcioroméite ${ }^{20}$ and $\mathrm{Ca}_{2} \mathrm{Sb}_{2} \mathrm{O}_{7}$ (Ref. 17). 
ASSOCIATED CONTENT

310 Supporting Information. The supplementary Information file (pdf file) contains: Text

311 (Experimental conditions), Figure S1; Figure S2; Figure S3; Table S1; and Table S2.

\section{AUTHOR INFORMATION}

\section{Corresponding Author}

314 *François Renard, Department of Geosciences, PGP, University of Oslo, box 1048, 0316

315 Blindern, Oslo, Norway (francois.renard@geo.uio.no)

\section{Author Contributions}

317 CVP and FR performed the experiments and wrote the manuscript. HK acquired and interpreted 318 the Raman and SEM data. GMH, GB and GO participated to the interpretations of the 319 experimental data and their consequences for the environment. All authors have given approval 320 to the final version of the manuscript.

\section{ACKNOWLEDGMENT}

322 The authors thank V. Rapelius for help with ICP-OES analyses at Münster University. CVP

323 acknowledges funding through the Marie Curie ITN CO2React. Funding from Labex

324 OSUG@2020 (Investissement d'avenir-ANR10-LABX56) is acknowledged. 
(1) Okkenhaug, G.; Zhu, Y. G.; Luo, L.; Lei, M.; Li, X.; Mulder, J. Distribution, speciation and availability of antimony $(\mathrm{Sb})$ in soils and terrestrial plants from an active $\mathrm{Sb}$ mining area. Environmental Pollution 2011, 159(10), 2427-2434.

(2) Stromseng, A. E.; Ljones, M.; Bakka, L.; Mariussen, E. Episodic discharge of lead, copper and antimony from a Norwegian small arm shooting range. Journal of Environmental Monitoring 2009, 11(6), 1259-1267. leachability of antimony in different wastes and waste handling facilities in Norway.

(4) Scheinost, A. C.; Rossberg, A.; Vantelon, D.; Xifra, I.; Kretzschmar, R.; Leuz, A. K.; spectroscopy. Geochimica et Cosmochimica Acta 2006, 70(13), 3299-3312.

(5) Okkenhaug, G.; Gebhardt, K. A. G.; Amstaetter, K.; Bue, H. L.; Herzel, H.; Mariussen, E.;

340 Almås, A. R.; Cornelissen, G.; Breedveld, G. D.; Rasmussen, G.; Mulder, J. Antimony (Sb) and lead $(\mathrm{Pb})$ in contaminated shooting range soils: $\mathrm{Sb}$ and $\mathrm{Pb}$ mobility and immobilization by iron based sorbents, a field study. Journal of Hazardous Materials 2016, 307, 336-343.

(6) Filella, M.; Belzile, N.; Chen, Y. W. Antimony in the environment: a review focused on natural waters: I. Occurrence. Earth-Science Reviews 2002a 57(1), 125-176. hydroxyapatite. Environmental Science \& Technology 2001, 35(18), 3669-3675. 
(8) Filella, M.; Belzile, N.; Chen, Y. W. Antimony in the environment: a review focused on natural waters: II. Relevant solution chemistry. Earth-Science Reviews 2002b, 59(1), 265-285.

(9) Nicolli, H. B.; Suriano, J. M.; Gomez Peral, M. A.; Ferpozzi, L. H.; Baleani, O. A. Groundwater contamination with arsenic and other trace elements in an area of the Pampa,

351 Province of Córdoba, Argentina. Environmental Geology 1989, 14(1), 3-16. and smelting area, China. Environmental Geochemistry and Health 2010, 32(5), 401-413.

355 (11) Brugger, J.; Gieré, R.; Graeser, S.; Meisser, N. The crystal chemistry of roméite. Contributions to Mineralogy and Petrology 1997, 127(1-2), 136-146. and other elements in samples taken from shooting ranges. Journal of Environmental Quality 2005 34(1), 248-254.

(13) Cornelis, G.; Van Gerven, T.; Snellings, R.; Verbinnen, B.; Elsen, J.; Vandecasteele, C.

361 Stability of pyrochlores in alkaline matrices: Solubility of calcium antimonate. Applied Geochemistry 2011, 26, 809-817. oxyanionic metalloid and metal species in alkaline solid wastes: a review. Applied Geochemistry 2008, 23(5), 955-976. 
(15) Ruiz-Agudo, E.; Putnis, C. V. Direct observations of mineral-fluid reactions using atomic force microscopy: the specific example of calcite. Mineralogical Magazine 2012, 76, 227-253.

(16) Edwards, H.G.M.; Villar, S.E.J.; Jehlicka, J.; Munshi T. FT-Raman spectroscopic study of calcium-rich and magnesium-rich carbonate minerals. Spectrochimica Acta Part A 2005, 61, $2273-2280$.

(17) Gedzeciviute, V.; Welter, N.; Schüssler, U.; Weiss, C. Chemical composition and colouring agents of Roman mosaic and millefiori glass, studied by electron microprobe analysis and Raman microspectroscopy. Archaeological and Anthropological Sciences 2009, 1, 15-29.

(18) Itukara, T.; Sasai, R.; Itoh, H. Detoxification of antimonic contaminated water and precipitation recovery of antimony by mineralization under hydrothermal condition. Chemical Letters 2007, 36, 524-525.

(19) King, H. E.; Mattner, D. C.; Plümper, O.; Geisler, T.; Putnis, A. Forming cohesive calcium oxalate layers on marble surfaces for stone conservation. Crystal Growth Design 2014, $14,3910-3917$.

(20) Biagioni, C.; Orlandi, P.; Nestola, F.; Bianchin, S. Oxycalcioromeite, $\mathrm{Ca}_{2} \mathrm{Sb}_{2} \mathrm{O}_{6} \mathrm{O}$, from Buca della Vena mine, Apuan Alps, Tuscany, Italy: a new member of the pyrochlore supergroup. Mineralogical Magazine 2013, 77, 3027-3038.

383 (21) Renard, F.; Montes-Hernandez, G.; Ruiz-Agudo, E.; Putnis, C. V. Selenium incorporation 384 into calcite and its effect on crystal growth: An atomic force microscopy study. Chemical Geology 2013, 340, 151-161. 
(22) Putnis, C. V.; Renard, F.; King, H.; Montes-Hernandez, G.; Ruiz-Agudo, E. Sequestration

387 of selenium on calcite surfaces revealed by nanoscale imaging. Environmental Science \& 388 Technology 2013, 47, 13469-13476.

(23) Renard, F.; Putnis, C. V.; Montes-Hernandez, G.; Ruiz-Agudo, E.; Hovelmann, J.; Sarret,

390 G. Interactions of arsenic with calcite surfaces revealed by in-situ nanoscale imaging.

391 Geochimica et Cosmochimica Acta 2015, 159, 61-79.

392

(24) Ruiz-Agudo, E.; King, H. E.; Patiño-López, L. D.; Putnis, C. V.; Geisler, T.; Rodriguez-

393 Navarro, C.; Putnis, A. Control of silicate weathering by interface-coupled dissolution-

394 precipitation processes at the mineral-solution interface. Geology 2016, 44(7), 567-570.

395 (25) Putnis, A.; Putnis, C. V. The mechanism of reequilibration of solids in the presence of a 396 fluid phase. Journal of Solid State Chemistry 2007, 180(5), 1783-1786.

397 (26) Putnis, A. Mineral replacement reactions. Reviews in Mineralogy and Geochemistry 2009, 398 70(1), 87-124.

399 (27) Teng, H.H. How ions and molecules organize to form crystals. The mineral-water 400 interface. Elements 2013, 9, 189-194.

401 (28) Gebauer, D.; Kellermeier, M.; Gale, J.D.; Bergström, L.; Cölfen H. Pre-nucleation clusters 402 as solute precursors in crystallization. Chemical Society Reviews 2014, 43, 2348-2371.

403 (29) Chelazzi, L.; Borrini, D.; Bonazzi, P. $\mathrm{Ca}_{2} \mathrm{Sb}_{2} \mathrm{O}_{7}-\mathrm{Ca}_{3} \mathrm{Mn}^{2+} \mathrm{Sb}_{4}{ }^{5+} \mathrm{O}_{14}$ pseudo-binary system: 404 Synthesis and characterization by X-ray powder diffraction. Solid State Sciences 2011, 13, 195405 197. 
406 (30) Aia, M. A.; Mooney, R. W.; Hoffman, C. W. W. An X-Ray Study of pyrochlore 407 Fluoantimonates of calcium, cadmium, and manganese. Journal of The Electrochemical Society 408 1963, 110, 1048-1054.

409 (31) Putnis, A. Mineral replacement reactions: from macroscopic observations to microscopic 410 mechanisms. Mineralogical Magazine 2002, 66(5), 689-708.

411 (32) Oorts, K.; Smolders, E.; Degryse, F.; Buekers, J.; Gascó, G.; Cornelis, G.; Mertens, J. 412 Solubility and toxicity of antimony trioxide $\left(\mathrm{Sb}_{2} \mathrm{O}_{3}\right)$ in soil. Environ. Sci. Technol. 2008, 42, 4134378. 